\title{
ABUNDANCE OF AQUATIC INSECTS IN RELATION TO PHYSICO- CHEMICAL PARAMETERS OF TWO HIGHLY POLLUTED RIVERS SITALAKKHYA AND THE BURIGANGA
}

\author{
Sanjida Hossain, Abu F. M. Aslam¹, Badhan Saha* and Abdul Jabber Howlader \\ Department of Zoology, Jahangirnagar University, Savar, Dhaka-1342, Bangladesh
}

\begin{abstract}
Diversity of aquatic insects in relation to the physicochemical parameters of the river Buriganga and Shitalakhya were studied from January to December 2013. A total of 9,891 individuals of aquatic insects representing 22 families under 6 orders were collected and identified. Higher number of insects were recorded from the river Shitalakhya $(5,493)$ than the river Buriganga $(4,398)$. Representatives of the family Culicidae were found to be dominant in the river Buriganga (23.28\%) than Shitalakhya $(20.70 \%)$. Specimens under the order Ephemeroptera and Trichoptera were found only in the river Shitalakhya. The highest diversity of Shannon Weiner Index (2.98), Evenness (0.98) and Taxa Richness (0.98) were recorded in the river Shitalakhya than the river Buriganga. This indicated the less pollution and presence of higher diversity of aquatic insects in the Shitalakhya river. The highest temperature, $\mathrm{pH}, \mathrm{EC}$, TDS, COD was observed in Buriganga in dry season and highest DO was observed in Shitalakhya in monsoon. From the present investigation it may be concluded here that the river Buriganga was more polluted than the river Shitalakhya.
\end{abstract}

Key words: Aquatic insect, physicochemical parameters, River Buriganga River Shitalakhya

\section{INTRODUCTION}

Aquatic ecosystems are being continually polluted by anthropogenic activities especially by industrial effluents. Aquatic insects play very important role in the ecosystem, not only do they serve as food for fish, amphibians, and aquatic birds, but also they are involved in the breakdown of organic matter and nutrients (Mohiuddin et al. 2011). Most of the rivers in the urban areas of the developing world are the end points of effluents discharged from the industries (Suthar et al. 2010). It has been reported that the water pollution in the two important rivers of Bangladesh namely the Buriganga and the Shitalakhya is now reaching to the highest level (Ahmad et al. 2010). Aquatic insects are used to assess the "health" of a river (Antonio and Barros 2001). A more favorable water quality index would be characterized by finding sensitive as well as tolerant organisms (Zakir et al. 2006).

The use of aquatic insects for assessing water quality provides information to environmental managers and decisions makers to take justifiable actions in regards to the state and quality of water bodies. The river Buriganga running by

\footnotetext{
* Author for correspondence: ${ }^{1}$ Soil and Environment section, Biological Research Division, Bangladesh Council of Scientific and Industrial Research (BCSIR) Laboratories, Dhaka, Bangladesh.
} 
the side of the Dhaka City, the capital of Bangladesh, is one of the most important rivers in Bangladesh (Islam et al. 2006). The river Shitalakhya is one of the most prominent rivers in the flood plain region of Bangladesh. It is located in Narayanganj City, the second most vital industrial zone of the country. Moreover, the river is the route of the communication with Chandpur, Chittagong as the port of cargo. Besides these, the people live on and around these two rivers utilizing water for their household washing, bathing and other necessary daily works. The risks of pollution impact are rising upwards sequentially (WARPO, 2000). The present study was conducted to investigate the composition, diversity, and distribution of aquatic insects in relation to the physicochemical properties of the rivers Buriganga and Shitalakhya. This may also help to evaluate the pollution status of the two important rivers of Bangladesh.

\section{MATERIAL AND METHODS}

Water samples and aquatic insects were collected from the river Buriganga and the Shitalakhya January to December, 2013 during. Three sampling sites were selected for each of the river and the names of the sampling location for their latitudes and longitudes are shown in the Table 1.

Table 1. Description of the sampling sites of two rivers

\begin{tabular}{|c|c|c|c|c|}
\hline \multirow{2}{*}{$\begin{array}{l}\text { Name of the } \\
\text { rivers }\end{array}$} & \multirow{2}{*}{$\begin{array}{l}\text { Sampling } \\
\text { locations }\end{array}$} & \multirow[t]{2}{*}{ Description of the locations } & \multicolumn{2}{|c|}{ GPS position } \\
\hline & & & Latitude & Longitude \\
\hline \multirow[t]{3}{*}{ Buriganga } & B1 & $\begin{array}{l}\text { Char Saiyedpur, Kathpotti, } \\
\text { Narayayanganj }\end{array}$ & $23^{\circ} 34^{\prime} 54.1^{\prime \prime} \mathrm{N}$ & $90^{\circ} 30^{\prime} 04.0 \prime \mathrm{E}$ \\
\hline & B2 & $\begin{array}{l}\text { Fatulla Launch Terminal, } \\
\text { Narayanganj }\end{array}$ & $23^{\circ} 38^{\prime} 27.5^{\prime \prime} \mathrm{N}$ & $90^{\circ} 28^{\prime} 21.2 ” \mathrm{E}$ \\
\hline & B3 & Hazaribagh, Dhaka & $23^{\circ} 42^{\prime} 00^{\prime \prime N}$ & $90^{\circ} 25^{\prime} 00^{\prime \prime} \mathrm{E}$ \\
\hline \multirow[t]{3}{*}{ Shitalakhya } & $\mathrm{S} 1$ & $\begin{array}{l}\text { Hajiganj Launch Ghat, } \\
\text { Narayanganj }\end{array}$ & $23^{\circ} 38^{\prime} 00.8^{\prime \prime} \mathrm{N}$ & $90^{\circ} 30^{\prime} 56.2 " \mathrm{E}$ \\
\hline & $\mathrm{S} 2$ & Launch Terminal, Narayanganj & $23^{\circ} 36^{\prime} 57.3 ” \mathrm{~N}$ & $90^{\circ} 30^{\prime} 21.1$ ”E \\
\hline & S3 & Kachpur Bridge, Narayanganj & $23^{\circ} 42^{\prime} 12.8 ” \mathrm{~N}$ & $90^{\circ} 30^{\prime} 57.0 ” \mathrm{E}$ \\
\hline
\end{tabular}

Collection of water samples and analysis: Water samples were collected fortnightly from each sampling location with $200 \mathrm{ml}$ plastic containers. The containers were pre-washed with nitric acid each time to remove any form of contaminants. The water samples were brought to the Soil and Environment Section of BCSIR lab of Dhaka and preserved in refrigerator temporarily until analysis. Water $\mathrm{pH}$ was determined by glass electrode using $\mathrm{pH}$ meter (Sense Ion, 156; HACH, USA). The EC of water samples was directly determined by EC meter (Sense Ion, 156; HACH, USA) in $\mu \mathrm{s} / \mathrm{cm}$. The total dissolved solid (TDS) was determined directly by TDS meter (2100 Q; HACH, USA). Dissolved oxygen 
of water samples was determined in the field by DO meter (HQ 30 D; HACH, USA). COD was determined with COD kit (Cat. 21259-15; HACH, USA). Average values of each parameter were recorded and presented in the form of their seasonal variations.

Collection of aquatic insects and identification: Adult insects were collected from the water surface of each sampling location using a dip-net. Insects collected were preserved in $70 \%$ ethanol in jars. All samples collected were taken to the Entomology laboratory of the Department of Zoology in Jahangirnagar University for identification. The insects were identified using microscope. The specimens were identified on the basis of the external morphology. Identification of the various taxa were done following available keys (Ameen et al. 1982; Ameen and Nessa 1985, Khan et al. 1997).

Analysis of data: Data were analysed using Microsoft Excel. Diversity and other indices were calculated using the following formulas:

Taxa richness (R): The taxa richness was based solely on the number of taxa found in the given area and does not reflect the relative dominance of species. The formula is: $\mathrm{R}=\mathrm{s}$ ( $\mathrm{s}=$ the number of taxa).

Shannon-wiener index $(H)$ : This index was determined by both the number of species and the even distribution of individuals among those species (Niklaus et al. 2001). The formula is

$$
H=-\sum_{i=1}^{n} p i \ln p i
$$

$\mathrm{Pi}$, relative abundance $=\mathrm{ni} / \mathrm{N}$

$\mathrm{ni}=$ number of individuals in species $\mathrm{i}$

$\mathrm{N}=$ total number of individuals in all species $\mathrm{H}$

Evenness (E): Using species richness (R) and the Shannon-Wiener index (H), evenness of a taxa was computed using following formula:

$\mathrm{E}=\mathrm{H} / \ln (\mathrm{R})$

\section{RESULTS AND DISCUSSION}

A total of, 9891 individuals of aquatic insects having representatives from 22 families under 6 orders were identified (Table 2).

Culicidae was found as the dominant family in both the rivers (Buriganga $23.28 \%$ and Shitalakhya 20.70\%). In the river Buriganga, the abundance 
Table 2. Number and seasonal abundance of aquatic insect communities in the river Buriganga (B) and Shitalakhya (S)

\begin{tabular}{|c|c|c|c|c|c|c|c|c|c|c|c|}
\hline \multirow[t]{2}{*}{ Order Name } & \multirow[t]{2}{*}{ Family Name } & \multicolumn{2}{|c|}{ Dry Season } & \multicolumn{2}{|c|}{ Pre Monsoon } & \multicolumn{2}{|c|}{ Monsoon } & \multicolumn{2}{|c|}{ Post Monsoon } & \multicolumn{2}{|c|}{ Percentage (\%) } \\
\hline & & B & $\mathrm{S}$ & $\mathrm{B}$ & $\mathrm{S}$ & $\mathrm{B}$ & $\mathrm{S}$ & B & $\mathrm{S}$ & B & $\mathrm{S}$ \\
\hline Ephemeroptera & Ephimeridae & 0 & 0 & 0 & 25 & 0 & 0 & 0 & 0 & - & 0.43 \\
\hline \multirow[t]{5}{*}{ Odonata } & Aeshnidae & 5 & 14 & 71 & 90 & 44 & 57 & 19 & 26 & 2.98 & 3.19 \\
\hline & Libellulidae & 23 & 26 & 49 & 63 & 35 & 48 & 23 & 32 & 2.79 & 2.88 \\
\hline & Calopterygidae & 26 & 21 & 48 & 62 & 29 & 41 & 20 & 28 & 2.64 & 2.59 \\
\hline & Lestidae & 13 & 23 & 63 & 77 & 39 & 47 & 11 & 17 & 2.70 & 2.80 \\
\hline & Coenagrionidae & 31 & 24 & 50 & 64 & 35 & 50 & 10 & 16 & 2.70 & 2.63 \\
\hline \multirow[t]{4}{*}{ Hemiptera } & Corixidae & 65 & 63 & 38 & 51 & 81 & 99 & 74 & 91 & 5.53 & 5.19 \\
\hline & Notonectidae & 31 & 30 & 30 & 41 & 66 & 79 & 58 & 70 & 3.97 & 3.75 \\
\hline & Belostomatidae & 36 & 35 & 41 & 51 & 97 & 118 & 85 & 101 & 5.55 & 5.20 \\
\hline & Gerridae & 40 & 41 & 83 & 97 & 160 & 209 & 129 & 174 & 8.83 & 8.89 \\
\hline \multirow[t]{6}{*}{ Coleoptera } & Haliplidae & 27 & 44 & 25 & 34 & 48 & 59 & 32 & 39 & 2.83 & 3.00 \\
\hline & Dytiscidae & 41 & 59 & 45 & 51 & 49 & 68 & 38 & 52 & 3.71 & 3.92 \\
\hline & Noteridae & 33 & 58 & 38 & 52 & 69 & 87 & 35 & 49 & 3.75 & 4.20 \\
\hline & Gyrinidae & 40 & 57 & 52 & 63 & 75 & 93 & 48 & 59 & 4.61 & 4.64 \\
\hline & Coccinellidae & 18 & 49 & 63 & 81 & 68 & 83 & 26 & 35 & 3.75 & 4.23 \\
\hline & Curculionidae & 18 & 38 & 40 & 54 & 57 & 70 & 18 & 28 & 2.85 & 3.24 \\
\hline Trichoptera & Rhyacophilidae & 0 & 4 & 0 & 13 & 0 & 19 & 0 & 25 & - & 1.04 \\
\hline \multirow[t]{5}{*}{ Diptera } & Culicidae & 106 & 105 & 222 & 227 & 147 & 184 & 314 & 357 & 17.94 & 15.89 \\
\hline & Chironomidae & 155 & 128 & 134 & 130 & 86 & 108 & 104 & 124 & 10.89 & 8.92 \\
\hline & Simuliidae & 61 & 81 & 20 & 28 & 21 & 34 & 44 & 55 & 3.13 & 3.38 \\
\hline & Tabanidae & 16 & 10 & 0 & 0 & 33 & 49 & 47 & 60 & 2.06 & 2.03 \\
\hline & Syrphidae & 10 & 20 & 45 & 64 & 48 & 62 & 24 & 43 & 2.72 & 3.23 \\
\hline
\end{tabular}


was followed by Chironomidae $(9.62 \%$,) Gerridae $(8.83 \%$,) Corixidae $(5.53 \%$,) Gyrinidae $(4.61 \%)$ and the least dominant family was Tabanidae $(2.06 \%$.) In contrast, the Shitalakhya supported a slightly different aquatic insect community. The abundance of the family Gerridae was $8.89 \%$, followed by Chironomidae $8.82 \%$, Belostomatidae 5.20\%, Corixidae 5.19\%, Gyrinidae $4.64 \%$. The least dominant families in the river Shitalakhya were Ephemeridae 0.43\% and Rhyacophilidae $1.04 \%$. Ohiokhioya et al. (2009) studied the aquatic insects inhabiting in the river Okhuo of Africa and reported their abundance as Ephemeroptera $>$ Odonata $>$ Coleoptera $>$ Diptera $>$ Plecoptera $>$ Trichoptera.

Ameen and Nessa (1985) described twenty three species of aquatic Hemiptera from ponds and lakes in and around Dhaka city. Khan et al. (1997) identified larvae of thirty Chironomidae species of order Diptera from central east and south-east of Bangladesh. Armitage (1983) considered the members of Ephemeroptera, Plecoptera, Trichoptera as sensitive to environmental stress. So it is assumed that the condition of river Shitalakhya is cleaner than the river Buriganga as the representatives of order Ephemeroptera and Trichoptera were found only in the river Shitalakhya. Dinakar and Anbalagan (2006) showed anthropogenic impacts on aquatic insects in six streams of South Western Ghats of India. Thani and Phalaraksh (2008) also studied the aquatic insect's diversity and water quality of Mekong river of Thailand. They found that highest number of aquatic insects were from the order Ephemeroptera. In the present study the order Ephemeroptera and Trichoptera were found only in river Shitalakhya but not in the river Buriganga. So, it can be said that the water quality of river Shitalakhya is much better than the river Buriganga and is less affected with anthropogenic activities.

Wahizatul et al. (2011), discovered that Culicidae was probably the most diverse and abundant group among all stream macroinvertebrates. The number of Chironomidae was higher in the Buriganga than the Shitalakhya. In dry season, the highest numbers of aquatic insects were recorded from the order Diptera under the family Chironomidae (72) in the river Buriganga. Pinder (1986) also described the family Chironomidae as the most abundant group in freshwater communities in Thailand. In pre-monsoon, the order Ephemeroptera emerged in river Shitalakhya and highest numbers of individuals were recorded from the family Ephemeridae (16) at sampling location S1. In monsoon, all the orders except Ephemeroptera emerged enormously and a large number of individuals under the order Odonata, Hemiptera, Coleoptera, Trichoptera and Diptera were recorded from both the rivers. According to Ohiokhioya et al. (2009) community composition varied seasonally, with a trend toward a declining proportion during the rainy season and increasing proportion during the dry season. The reason may be that they worked with pollution free river.

In post-monsoon, Dipteran family Tabanidae (37) and Trichopteran family Rhyacophillidae (27) showed increased numbers of individuals at sampling location S1 in the river Shitalakhya. Antonio and Barros (2001) reported that the 
number of Tabanidae increased in October, coincided with the beginning of the rainy season. The daily abundance of the total adults of the order Trichoptera reached a maximum on September (Ghosh and Singh, 2005). These results of their works were similar with the findings of present study.

Seasonal diversity and quality indices of the aquatic insects from different sampling locations of the river Buriganga and Shitalkhya are presented in the Table 3. The highest values of Shannon Weiner Index (2.98), Evenness (0.98) and Taxa Richness (0.98) were recorded in the river Shitalakhya and lowest values of all those indices were found in the river Buriganga indicated the presence of higher diversity of aquatic insects in the river Shitalakhya than the river Buriganga.

Abhijna et al. (2013) declared Vellayani lake of India which maintained better quality with the highest values of same diversity indices. The seasonal variation in the physicochemical properties of the water samples collected from the river Buriganga and Shitalakhya are shown in Table 4.

Temperature of river Buriganga and Shitalakhya was found to vary from $25.26^{\circ} \mathrm{C}$ to $29.27^{\circ} \mathrm{C}$ and $24.91^{\circ} \mathrm{C}$ to $29.65^{\circ} \mathrm{C}$ respectively throughout the year. Ahmad et al. (2010) found that temperature varied from $22.9^{\circ} \mathrm{C}$ to $36.0^{\circ} \mathrm{C}$ along the river Shitalakhya in dry season. Such high temperature in these rivers may be due to outfalls of the thermal effluent of cement factories, dyeing factories etc. standing beside the bank of the rivers. The highest $\mathrm{pH}$ (7.59) was recorded during pre-monsoon in the river Buriganga and the lowest $\mathrm{pH}$ (7.01) was recorded in post monsoon in the river Shitalakhya. Similar type of investigation

Table 3. Seasonal diversity and quality indices of aquatic insects from different sampling locations of the river Buriganga (B) and Shitalakhya (S)

\begin{tabular}{lcccc}
\hline Season & $\begin{array}{c}\text { Sampling } \\
\text { Locations }\end{array}$ & $\begin{array}{c}\text { Shannon-Wiener's } \\
\text { Diversity Index }\end{array}$ & Evenness & Taxa Richness \\
\hline \multirow{5}{*}{ Dry Season } & B1 & 2.58 & 0.86 & 20 \\
& B2 & 2.42 & 0.81 & 20 \\
& B3 & 0.89 & 0.50 & 6 \\
& S1 & 2.71 & 0.89 & 21 \\
& S2 & 2.56 & 0.85 & 20 \\
& S3 & 1.06 & 0.51 & 8 \\
\hline \multirow{5}{*}{ Pre-Monsoon } & B1 & 2.80 & 0.95 & 19 \\
& B2 & 2.74 & 0.93 & 19 \\
& B3 & 1.66 & 0.72 & 10 \\
& S1 & 2.98 & 0.98 & 21 \\
& S2 & 2.86 & 0.95 & 20 \\
& S3 & 2.66 & 0.89 & 20 \\
\hline
\end{tabular}




\begin{tabular}{lllll}
\hline \multirow{3}{*}{ Monsoon } & B1 & 2.88 & 0.96 & 20 \\
& B2 & 2.84 & 0.95 & 20 \\
& B3 & 2.06 & 0.83 & 12 \\
& S1 & 2.95 & 0.97 & 21 \\
& S2 & 2.86 & 0.96 & 20 \\
Post- & S3 & 2.01 & 0.81 & 12 \\
\hline Monsoon & B1 & 2.71 & 0.91 & 20 \\
& B2 & 2.54 & 0.86 & 19 \\
& B3 & 1.42 & 0.65 & 9 \\
& & & & \\
& S1 & 2.85 & 0.94 & 21 \\
& S2 & 2.63 & 0.88 & 20 \\
\hline
\end{tabular}

was carried out by Dubey et al. (2006) with the river Yamuna of India and recorded low $\mathrm{pH}$ value during monsoon period. According to the findings of Rahman et al. (2012) EC values increased in pre-monsoon in the river Buriganga and the Shitalakhya. In the river Buriganga the highest EC $(661.67 \mu \mathrm{s} / \mathrm{cm})$ was recorded in pre-monsoon, and the lowest $(198 \mu \mathrm{s} / \mathrm{cm})$ was recorded in postmonsoon in the river Shiatalakhya. Ahmad et al. (2011) found TDS values were higher in winter season than that of rainy season in the river Shitalakhya. This may be because, in rainy season the polluted water was diluted with the rain water, thus reduce TDS values. In present study, the highest DO $(6.15 \mathrm{mg} / \mathrm{l})$ was observed in post-monsoon in the river Shitalakhya and the lowest (3.37 $\mathrm{mg} / \mathrm{l})$ was recorded in dry season in the river Buriganga. Because in dry season the flow of water in the river was very low and concentration of pollutants was very high. Industrial wastes may also caused depletion of DO by chemical reaction, (Chakraborty et al. 2013). It was evident from the results of the present investigation that the pollution of both the rivers were deadly hazardous upon the status of aquatic biodiversity. So awareness should be developed to stop over pollution in the rivers through unplanned industrialization and urbanization because rivers are one of the most potential natural resources that enrich our poor country from various aspects and this information may help Government and Non-Government organizations to plan long term strategies to save our aquatic ecosystem. 
Table 4. Seasonal variation in the physicochemical parameters of water samples collected from different sampling locations of the river Buriganga (B) and Shitalakhya (S)

\begin{tabular}{|c|c|c|c|c|c|c|c|c|}
\hline \multirow{3}{*}{ Parameters } & \multicolumn{8}{|c|}{ Name of the seasons } \\
\hline & \multicolumn{2}{|c|}{ Dry season } & \multicolumn{2}{|c|}{ Pre monsoon } & \multicolumn{2}{|c|}{ Monsoon } & \multicolumn{2}{|c|}{ Post monsoon } \\
\hline & $\mathrm{B}$ & $\mathrm{S}$ & $\mathrm{B}$ & $\mathrm{S}$ & B & $\mathrm{S}$ & $\mathrm{B}$ & $\mathrm{S}$ \\
\hline Temperature oC & $25.26 \pm 0.60$ & $24.91 \pm 0.79$ & $28.77 \pm 0.93$ & $28.92 \pm 0.67$ & $29.27 \pm 0.43$ & $29.65 \pm 0.28$ & $26.80 \pm 0.25$ & $26.34 \pm 0.67$ \\
\hline $\mathrm{pH}$ & $7.33 \pm 0.09$ & $7.12 \pm 7.02$ & $7.587 \pm 0.03$ & $7.39 \pm 0.04$ & $7.37 \pm 0.04$ & $7.33 \pm 0.13$ & $7.30 \pm 0.01$ & $7.01 \pm 0.05$ \\
\hline $\begin{array}{l}\text { Electrical Conductivity } \\
\text { (EC) } \mu \mathrm{s} / \mathrm{cm}\end{array}$ & $564.33 \pm 49.09$ & $455.67 \pm 47.19$ & $661.67 \pm 45.32$ & $610.67 \pm 14.52$ & $378.67 \pm 60.97$ & $380.33 \pm 96.31$ & $217.33 \pm 30.43$ & $198.00 \pm 31.94$ \\
\hline $\begin{array}{l}\text { Total Dissolved Oxygen } \\
\text { (TDS) } \mathrm{mg} / 1\end{array}$ & $279.00 \pm 55.97$ & $193.33 \pm 35.27$ & $390.67 \pm 26.41$ & $380.33 \pm 10.40$ & $106.33 \pm 11.57$ & $124.00 \pm 36.01$ & $125.33 \pm 16.76$ & $100.67 \pm 9.56$ \\
\hline $\begin{array}{l}\text { Chemical Oxygen Demand } \\
\text { (COD) } \mathrm{mg} / 1\end{array}$ & $3.37 \pm 0.45$ & $4.26 \pm 0.32$ & $3.80 \pm 0.32$ & $4.20 \pm 0.23$ & $5.38 \pm 0.36$ & $6.15 \pm 0.15$ & $5.96 \pm 0.46$ & $6.03 \pm 0.41$ \\
\hline Dissilved Oxygen (DO) & $419.79 \pm 33.5$ & $261.94 \pm 36.25$ & $345.66 \pm 27.67$ & $245.67 \pm 27.67$ & $164.36 \pm 35.89$ & $101.65 \pm 18.00$ & $235.45 \pm 38.82$ & $146.45 \pm 21.36$ \\
\hline
\end{tabular}




\section{LITERATURE CITED}

ABHIJNA, U.G., RATHEESH, R. and KUMAR, A.B. 2013. Distribution and diversity of aquatic insects of Vellayani lake in Kerala. J. Environ. Biol. 34: 605-611.

AHMAD, M.K., ISLAM, S., RAHMAN, S., HAQUE, M.R. and ISLAM, M.M. 2010. Heavy metals in water, sediment and some fishes of Buriganga River, Bangladesh. Int. J. Environ. Res. 4(2): 321-332.

AHMAD, M.K., DAS, M. and ISLAM, M.M. 2011. Physico-chemical properties of tannery and textile effluents and surface water of river Buriganga and Karnatoli, Bangladesh. World App. Sci. J. 12(2): 152-159.

AMEEN, M., AKHTER, R.U.S. and RABBI, M.F. 1982. Final instar larvae of common damselflies (Odonata : Zygoptera) of Dhaka city and their identification key. Bangladesh J. Zool. 10(2): 81-91.

AMEEN, M. and NESSA, S.K. 1985. A Preliminary identification key to the aquatic Hemiptera of Dhaka city. Bangladesh J. Zool. 13(1): 49-60.

ANTONIO, T. and BARROS, M. 2001. Seasonality and relative abundance of Tabanidae (Diptera) captured on Horses in the Pantanal, Brazil. Mem. Inst. Oswaldo cruz. Rio de Janeiro. 96(7): 917-923.

ARMITAGE, P.D. 1983. The effects of mine drainage and organic enrichment on benthos in the River Nent system, Northern Pennines. Hydrobiology. 74: $119-128$.

CHAKRABORTY, C., HUQ, M.M., AHMED, S., TABASSUM, T. and MIAH, R.M. 2013. Analysis of the causes and impacts of water pollution of Buriganga river: A critical study. Int. J. Sci. and Technol. Res. 2(9): 2277-8616.

DINAKAR, S. and ANBALAGAN, S. 2006. Seasonal variation and substrate selection of aquatic insects in a small stream Sirumalai hills of southern Western Ghats. $J$. Aquatic Biol. 21: 37-42.

DUBEY, K.K., GIRRI, A.K. and LAGARKHA, R. 2006. Seasonal changes of water quality parameters of Yamuna river at Kalpi, Distt- Jalaun. Nat. J. Life Sci. 2: 403-408.

GHOSH, M. and SINGH, S.P. 2005. Review on phytoremediation of heavy metals and utilization of its byproducts. J. App. Ecol. 3(1): 1-18.

ISLAM, M.M., HAQUE, M.R., AHMED, M.K. and MANNAF, M.A. 2006. Seasonal variation of heavy metals concentrations in Gudusia chapra inhabiting the Sundarban mangrove forest. J. NOAMI. 23(1): 1-21.

KHAN, M.A.G., RAHMAN, M. and ISLAM, S. 1997. Chironomid larvae of central-east and south-east Bangladesh-Keys and diagnosis with notes on ecology and distribution. Bangladesh J. Zool. 25(1): 29-46.

MOHIUDDIN, K.M., OGAWAY, Z.H.M., OTOMO, K. and SHIKAZONO, N. 2011. Heavy metals contamination in water and sediments of an urban river in a developing country. Int. J. Enviro. Sci. Technol. 8: 723-736.

NIKLAUS, P.A., LEADLEY, P.W., SCHMID, B. and KORNER, C.H. 2001. A long-term field study on biodiversity $\mathrm{X}$ elevated $\mathrm{CO}_{2}$ interactions in grassland. Ecological Monographs. 71: 341-356.

OHIOKHIOYA, T., IMBOOBE, T. and OHIOZEBAE, E. 2009. Pollution status of a tropical forest river using aquatic insects as indicators. African J. Ecol. 48(1): 232-238. 
PINDER, L.C.V. 1986. Biology of freshwater Chironomidae. Annual Review of Entomology. 31: 1-23.

RAHMAN, A., ZAFOR, M.A. and KARIM, S. 2012. Analysis and comparison of surface water quality parameters in and around Dhaka City. International J. Civil Engineering and Technol. 3(2): 07-15.

SUTHAR, S., SHARMA, J., CHABUKDHARA, M., and NEMA, A.K. 2010. Water quality assessment of river Hindon at Ghaziabad, India: impact of industrial and urban wastewater. Environmental Monitoring and Assessment. 165: 103-112.

THANI, I. and PHALARAKSH, C. 2008. A preliminary study of aquatic insect diversity and water quality of Mekong river, Thailand. KKU Sci. J. 36 (Supplement): 95-106.

WAHIZATUL, A.A., LONG, S.H. and AHMAD, A. 2011. Composition and distribution of aquatic insect communities in relation to water quality in two freshwater streams of Hulu Terengganu, Terengganu. J. Sustainability Science and Management. 6(1): 148-155.

WARPO, 2000. National Water Management Plan Project, Ministry of Water Resource, Government of Bangladesh.

ZAKIR, H.M., SHARMA, S. and SHIKAZONO, N. 2006. Heavy metal pollution assessment in water and sediments of Turag river at Tongi area in Bangladesh. Int. J. Lak. Riv. 1: 85-96.

(Manuscript received on 25 April, 2015l; revised on 01 June 2015) 